\title{
Forward vs. Reverse Gear: The Politics of Proliferation and Resistance in the Italian Fascist State
}

\author{
Elizabeth L. Krause
}

\begin{abstract}
Gender serves as a useful category for historical analysis of the project of Italian fascist state-building, how it proceeded and how it became trapped in its own paradox. Fascist policies played upon normative and limited gender stereotypes of women as mothers and prolific bearers of children, yet in the process the dictatorship constructed women as political subjects for the first time in the history of the Italian state. This paper focuses on the fascists' demographics campaign - the Duce's politics of proliferation-and identifies the places in which subjects of fascism consciously chose to act in opposition to fascist ideologies. Resistance is discussed in terms of everyday acts of noncompliance with fascist directives regarding reproduction. The strategies of legitimation that the fascists used are explored.
\end{abstract}

Go back home and tell the women I need births, many births.

- Benito Mussolini (1927)

The Duce's first message to national delegates of the fascist women's organization in October 1927, to go home and make babies, was to become an official policy of the Italian dictatorship. Benito Mussolini sought to increase the population of Italy from 40 to 60 million in less than 25 years. Although the country was crowded and economic difficulties compelled large numbers of Italians to emigrate each year, the dictator's discourse conveyed the need for a larger body of fascist subjects. His demographic agenda put the politics of proliferation, that is, the politics of pressuring women to serve as prolific child-bearers in the name of the state, at the forefront of the state's agenda. Public rituals were invented to promote the cult of motherhood in the name of building a homogeneous nation-state. Such attempts at legitimation sought to help realize Massimo d'Azelio's famous slogan: "Now that we have made Italy, we must make Italians" (Schneider and Clough 1929:24).

Italy had consisted of fragmented states for centuries. The numerous kingdoms and grandduchies were officially unified into one national entity in 1861 (Barbagli and Kertzer 1990:371). By the late 1920s, however, the project of "making Italians" was largely unfulfilled. Local traditions still 
dominated political patriotism. People were more "accustomed to think of themselves as...Tuscans, Romans, Neapolitans, or Sicilians" than as Italians (Schneider and Clough 1929:24). In trying to overcome this regionalism, the fascist leaders made "every conceivable effort to impress the middleclass and intellectualist idea of Italian nationality on the masses, " according to Schneider and Cough. This totalizing effort directed attention away from other pressing issues, including class and "race, ${ }^{n 2}$ as well as the tension between North and South, which was often described as an urban/rural, modern/traditional conflict and expressed through the different issues facing industrial and agricultural workers.

The Duce's demographic campaign favored national goals over regional problems although, ironically, the ideal of motherhood relied upon images of peasant women. The historian Victoria de Grazia attributes the goal of population growth primarily to mercantilism and imperialist expansion. A large population was seen to promise cheap labor within Italy and hence to strengthen the nation economically; a large number of citizens was also seen as necessary for providing the fascists first with soldiers to conquer foreign territories and then with Italian subjects to populate and hence justify the colonies (de Grazia 1992:42). The demographic policies recognized the importance of women as state subjects, and this was a definite change from the liberal politics that had preceded fascism. The Duce's aim of nationalizing Italian mothers marked a new role for European women:

Up until the early twentieth century... "nationalizing the masses" largely referred to male subjects: the creation of hardened soldiers, dutiful taxpayers, disciplined workers, thrifty consumers, and ultimately, of course, predictable voters. By and large, women were excluded from those domains of concern (de Grazia 1992:6).

This paper explores the ramifications of Italian fascist policies that narrowly defined women by their capacity to bear children-lots of childrenwhose numbers were seen as critical for perpetuating the fascist state. A segue into women's roles as workers will also be necessary, for the fascist project tended to demonize women as workers and to glorify women as mothers. This investigation will lead me to several lines of inquiry: How did fascist propaganda that constructed "proper" roles for women and men assist in the project of state building? What traditions, public rituals, and documentation projects served to legitimize the "logic" and "morality" of fascist rule? And how did women-and men-challenge the state's hegemony in their everyday acts of resistance? Resistance will be cast in terms of 
oral histories of the working class in Turin, an industrial city in northern Italy, and anecdotes from the artisan class in Sicily.

Paradoxically, fascist policies played upon normative and limited gender stereotypes of women as mothers and prolific bearers of children, yet in the process the dictatorship constructed women as political subjects for the first time in the history of the Italian state. Efforts to produce ideal women became politicized. Ironically, then, political discourse sought to achieve one goal and invariably resulted in its opposite. This contradiction, as well as other disparities between fascist ideology and practice, trapped the dictatorship "in a paradox of its own making," in the words of de Grazia (1992:81). It is here that the regime became vulnerable to resistance, that the "fragility of hegemony" was exposed (Roseberry 1992).

\section{Thboretical Thembs on the State}

How can theories of the state help us to understand why paradox may be so primary to grasping the place, the moment, wherein the state becomes vulnerable to resistance? Philip Abrams has noted the difficulty of studying the state. Invoking Marx and Engels' The German Ideology, Abrams writes that "the most important single characteristic of the state is that it constitutes the 'illusory common interest' of a society" (1988:64). Abrams underscores the importance of the word "illusory" to argue that one of the primary functions of the state is to conceal class power. It logically follows from this approach that the ways in which the idea of the state's existence has been "constituted, communicated and imposed" (1988:69) become extremely important. Abrams argues that the real strength of the state, if it even exists as a unified thing, lies in its ideological power (1988:79). This notion helps us to understand the Italian fascist state and its politics of proliferation.

Many Italians living under fascism were able to see through the veneer of fascist discourses that claimed policies were for the "common interest" of the nation. However, the Italian people proved themselves to be agents more than actors - they weren't merely reading or acting out a script, but were showing their ability to see through false discourse and then to act in ways that threatened to subvert the official ideologies. This is not to say that ideologies themselves did not have material consequences; they did. In this sense, I accept Abrams' proposal that "we should...continue to take the idea of the state extremely seriously" (Abrams 1988:75). With Abrams I see the state as "an ideological project. It is first and foremost an exercise in legitimation" (Abrams 1988:76). 
What, then, is the best method for analyzing the state and its subjects, coercion and consent, struggle and resistance? Following Abrams' lead, I begin with a historical construction of the fascist state in order to avoid reification. The Popular Memory Group (PMG) argues that history cannot be divorced from the present and that the products of history carry with them an inherent political power. Their discussion of oral histories reminds us that "popular memories are constructed and reconstructed as part of contemporary consciousness" (PMG 1982:219). In other words, the way people remember the events of their lives cannot be removed from the current social, political, and economic context in which their memories are re-produced.

Yet what is often missing from oral history projects is a bridge between general social processes, which are typically the focus of history, and more specific "private" narratives, provided from personal memories (PMG 1982:234). A bridge between the public process of state formation and private narratives especially related to the politics of proliferation may be found in Luisa Passerini's oral histories of working people in Turin. These oral histories, which reflect upon the state project as it manifests itself in the everyday lives of working people, counterbalances the horror of abstraction (after Sayer 1991) that potentially exists in theoretical meanderings on the state.

Equally relevant are ideas expressed in Joan Scott's seminal paper on "Gender as a Useful Category for Historical Analysis" (1986). Scott urges scholars to consider the processes of change, reminding us that gender does not function exclusively in the realm of kinship; gender "is constructed as well in the economy and the polity" (1986:1068). Gender has traditionally been neglected in historical analyses, especially those related to politics and power as they pertain to government and the nation-state ${ }^{3}$ (Scott 1986; Fox-Genovese 1982). "[G]ender," Scott writes, "has been seen as antithetical to the real business of politics." The use of gender as an analytical category can shed light on particular historical processes, such as how the fascists legitimized their rule via discourses that regulated masculine and feminine behavior. As Scott has noted:

Gender provides a way to decode meaning and to understand the complex connections among various forms of human interaction. When historians look for the ways in which the concept of gender legitimizes and constructs social relationships, they develop insight into the reciprocal nature of gender and society and into the particular and contextually specific ways in which politics constructs gender and gender constructs politics (Scott 1986:1070). 
Viewing fascist state formation as a process rather than a fait accompli allows room for human agency and possibilities for negation, resistance, and reinterpretation. Acts of resistance in people's daily lives cannot be understood without viewing those people as gendered subjects. Silverblatt (1988:429) has underscored the significance of "calling attention to the intricate and conflicting social relations that constitute women in states, as well as to the pointed play of gender in state-making and state-subverting processes." Including gender in the analysis enriches our understanding of how the fascist state sought to achieve its dominance and of how men and women resisted that rule. A dialectic of historical forces-forces of "forward" and "reverse gear" - thus becomes possible.

Resistance to the hegemony of the state can be located in everyday acts. Central to the idea of the everyday is that while labor and productive activity are important for cultural critique, workers have "a social life, family life, political life; they have experiences outside the domain of labor" (Lefebvre 1988:78). In the acts of the everyday, we can begin to understand the subaltern consciousness, even though its members' voices are at times mere whispers beneath the hegemonic discourse (Guha and Spivak 1988).

The notion of the everyday is highly relevant to Gramsci's conception of hegemony, which informs this paper. Raymond Williams' interpretation may be useful:

Hegemony is then not only the articulate upper level of "ideology, "nor are its forms of control only those ordinarily seen as "manipulation" or "indoctrination." It is a whole body of practices and expectations, over the whole of living: our senses and assignments of energy, our shaping perceptions of ourselves and our world. It is a lived system of meanings and values - constitutive and constituting - which as they are experienced as practices appear as reciprocally confirming. It thus constitutes a sense of reality for most people in the society...It is, that is to say, in the strongest sense a "culture," but a culture which has also to be seen as the lived dominance and subordination of particular classes (Williams 1977:110).

William Roseberry (1992:23) argues that we should conceive of hegemonic processes as "state projects rather than state achievements." The implication, then, is that hegemony is fragile; it is not "a finished and monolithic ideological formation" but rather "a problematic, contested, political process of domination and struggle" (Roseberry 1992:11). Alonso describes "the production and reproduction of ideological hegemony" as "an ongoing process in which official and popular discourses struggle to advance and to defend social interests and values." Hegemony, therefore, is "constantly negotiated" (Alonso 1988a:48). If we understand hegemony 
in these ways - the Gramscian sense of dominance by consent within civil society and a force that is contestable-the civil realm of the everyday is where resistance becomes valid and powerful.

\section{"Revbrse Gbar" and Othbr Forms of Resistance}

In order to understand resistance, we cannot simply focus on institutional politics but must also pay attention to the politics of everyday life, to the ways in which power is experienced and negotiated outside of formal contexts, to the effects of power on identities and bodies (Alonso 1988b:27).

The conscious practice of coitus interruptus among the Sicilian artisan class is well-documented. The artisan class and way of life contributed to the possibilities for resisting the state: Artisans were well positioned to challenge the Church's teaching with regard to reproduction; they had a tradition that stretched back to the 19 th century of being among the literate vanguard who transmitted socialist ideas in rural Sicily. Until the 1920s, families with five to 13 children were the norm. Beginning in the 1920 s and particularly after 1930, the norm changed dramatically: Most families had only two or three children. The oral histories that Jane and Peter Schneider gathered from people in Villamaura who were adults during the fascist regime revealed how the transformation in family size came about. As devices for preventing contraception became expensive or unavailable, "artisan men adopted coitus interruptus with thoroughness and ideological commitment" (Schneider and Schneider 1984:259). The technique became known as la marcia in dietro or "reverse gear." The naming of this form of birth control coincided with the appearance of the first automobile in Sicily, and the Schneiders suggest that this modern mode of transportation inspired the term "reverse gear."

Informants agreed that avoidance of conception through "reverse gear" required "skill and control on the part of the husband, and considerable cooperation and communication between husband and wife, particularly if they cared (as most did) that the woman continue to experience sexual pleasure" (Schneider and Schneider 1984:259). The authors noted that "what seems remarkable about the artisans' recollections is the pride taken in the sacrifices that were made" (1984:259). The artisans told the researchers that only one couple was motivated by patriotism to raise a large family, "and they were ridiculed for having taken Mussolini so seriously" (Schneider and Schneider 1984:258).

I would suggest that "reverse gear" constituted a form of resistance rather than mere common sense because it was so consciously carried out 
within a larger discourse of nationalism. That people were resisting the fascist state's calls to make babies often did involve common-sense judgments about what was more practical, but the thesis that many decisions were made in direct opposition to fascist policy receives further support in Luisa Passerini's oral histories of Turinese workers (1979, 1982, 1986, 1987). These histories reveal that people were consciously resisting the fascist demographic policies, proclamations, and propaganda. Forgacs (1986) notes that conventional histories paint the subjects of fascism as compliant. Perhaps these histories were not looking for resistance in the right places: They may have been looking at public displays rather than at private, everyday forms.

Both men and women resisted the state's demographic policies. One man recalled his preference for doing "casual" work as a way to avoid paying the tax on celibacy, a tax levied against unmarried men between the ages of 25 and 65.4 When the agents of the state sent for him, he told them he was unemployed. "I'd dug my heels in so to speak," he said (Passerini 1987:151). Some men resented the request to create bigger families because, as Passerini writes, "it was taken as an attack on the identity of the ideal worker who was capable, far-sighted, self-disciplined” (1987:151). Another man told her:

At a meeting once at the Bianchi Centre in Piazza Statuto, they wanted me to have children-to go home and-if you'll excuse the expression-jump on the wife. But who would be so daft? There was already so much misery, damn it! So I couldn't swallow that.

Numerous women refused to comply with the large-family edict. One woman, Tosca, articulated her resentment of the demographics campaign: "Oh Fascism! The Duce! Have babies! Don't think of your husband, have babies, give me babies to slaughter. He only wanted boys. To make war. Then he made it." Another woman who had three children said, "I would have had more, but you didn't to spite Mussolini, you see" (Passerini 1987:150).

How did women prevent pregnancies, given the ban on contraceptive devices? Besides abstinence, male contraceptive "sheaths" (condoms) became available after the First World War, but they were expensive and difficult to obtain. "[P] urchasing sheaths was not the easiest of things to do socially in the fascist period, except by going to another neighborhood in a big city" (Passerini 1987:160). The primary method of prevention during the interwar period was coitus interruptus. This latter practice required the cooperation of both partners and even so was risky. 
When birth control failed, some women resorted to abortion. The estimates of illegal abortions under fascism are quite dramatic. Abortions were both self-inflicted using home remedies (such as inserting a parsley stalk into the uterus or drinking large doses of magnesium sulphate and quinine) or were performed for payment by medical personnel, midwives, self-trained specialists, or clandestinely by hacks. Each of these methods reflects a determination on the part of women to control their fertility. A great deal of courage was required to engage in this form of resistance. There were clearly risks involved in this decision to rebel against the fascist cult of motherhood: threats of prison, threats to health, and sometimes threats from relatives, including some husbands. Many women died of selfinduced abortions; others' bodies were badly damaged in the process. Women's stories expressed the personal terror, loneliness, excruciating pain, and anxiety that accompanied the choice to seek an abortion (Passerini 1987).

To quantify abortions during this period is difficult. Scholars have relied on abortion trials, criminal data, public health estimates, and oral testimonies to make estimates. A preponderance of people convicted of abortion offenses were from the literate social classes, and abortion appeared to be more common in the northern and urban regions. Data from working-class women in Turin revealed that "abortion was widely practiced as a form of birth control and was used by married women with children" (Passerini 1987:179). Indeed, the main effect of the bans on information and contraception was "to increase the acceptance of abortion" (de Grazia 1992:57). Unlike prewar Italy, in which abortion was considered a "bourgeois vice," abortion under fascism became "a widespread urban workingclass practice" (de Grazia 1992:58). Exactly how widespread it was is impossible to verify. But as Passerini (1987:180-181) suggests, the quantitative data, though flawed, show an unquestionable increase in abortion. The qualitative sources take the implications of abortion a step further: that women were assuming responsibility for birth control, thereby exercising a degree of control over their own bodies and lives, and in the process taking account of economic, biological, and cultural factors in making a reproductive decision.

A combination of factors led people to see through the false veneer of the dominant ideology - especially when their experiences conflicted with the official fascist rhetoric and propaganda. Paradox is central to creating gaps and lesions, to providing space for resistance. Under Italian fascism, the economics of families were pushed to the limit. Demographic policies pressed people to have bigger families when common sense argued for smaller ones; the message of government propaganda and laws was that 
only men should work outside the home, whereas the reality was that underemployment and low wages required entire families to seek employment as a means of survival (de Grazia 1992:81). As Noether notes, between 1931 and 1936, after the fascist moral order was articulated, "there was no wholesale withdrawal of women from employment" (Noether 1982:74). It was this central paradox-economic reality flying in the face of fascist rhetoric - that cast doubt on the legitimacy of the fascist state.

\title{
The Politics of Proliferation
}

\begin{abstract}
A nation exists not only because it has a history and territory, but because human masses reproduce from generation to generation. The alternative is servitude or the end. Italian fascists: Hegel the philosopher of the State said: "He who is not a father is not a man." - Benito Mussolini 1928 (in de Grazia 1992:41)
\end{abstract}

The politics of proliferation were among the Duce's favorite themes of discussion, as his numerous comments on the subject attest (de Grazia 1992:295). Mussolini's speeches constantly stressed that woman's moral place was within rural society where the home and family were central, rather than in the industrialized world where the birth rate declined (de Grand 1976:964). The famous slogan, "War is to man what motherhood is to woman," epitomizes the typing of gendered subjects under fascism (Birnbaum 1986:34). Several important questions worth asking are: What was at stake in the proclamations that invoked gender roles, such as the way in which statements equate virile manhood with fatherhood, or numerous other examples that naturalize women's biological role as reproducers and mothers? How was Mussolini reinscribing implicit conceptions of gender, and what effect did the casting of gender roles have on the legitimation project of the state? The literature on fascist Italy suggests that gender roles were critical to the fascist state project-its legitimacy, its reproduction, and its existence - and to the resistance that people expressed in their everyday lives.

Discourses articulated through state-related activities and institutions spoke to what Philip Corrigan and Derek Sayer (1991:3-4), in discussing state formation in England, described as "acceptable forms and images of social activity" and helped further the project of "moral regulation." The Duce as the figurehead of the Italian fascist state was legitimized as a sort of patriarch of the family writ large. This style of moral regulation lent credence to the state's legitimacy, because imagining the state as analogous to a big family was a powerful metaphor: It effectively made something that 
was normally very abstract-the state-into something that every Italian could relate to in his or her everyday life-the family.

Primarily at stake was state and national power. Mussolini viewed a more populous nation as more powerful, especially in terms of workers and soldiers. His campaign was aimed at reversing a trend toward decreased fertility that had begun in the 1880s (Caldwell 1986:116). Many critics, historically and recently, have seen folly in Mussolini's population edicts: Whole areas in Italy were on the verge of starvation in the early decades of the 20th century.

Coincident with the high rate of unemployment in the south came a ban on emigration at a time when foreign countries still had work to offer. In a December 1927, speech, the Duce urged his subjects to "have the courage to say that emigration is an evil" unless it were emigration to Italian colonies and possessions (Ebenstein 1934:161). This policy was linked to the goal of population growth. Also linked to this goal was a law forcing people who left the countryside for the city and lost their urban employment to be sent back to their rural homes. This edict was a way both to prevent the growth of political action in the cities and to keep birth rates at their highest possible, since rates tended to be higher in the country than in towns or cities (Ebenstein 1934:170).

Caldwell (1986:116) suggests that the demographic initiatives can be placed into four categories: incentives to marry, incentives to produce large families, bans on birth control, and prevention of infant mortality. It appears that despite the creation of a social-welfare state and corresponding tools such as the Opera Nazionale Maternita ed Infanzia (National Agency for Maternal and Infant Welfare), the negative aspects of the demographic campaign are what people have tended to remember (Passerini 1987:153). Perhaps this is because the policies were so uneven and so restrictive. For example, marriage loans were highly discriminatory. They were available to couples under the age of 26 , when the husband had Italian nationality and an income of up to 12,000 lire a year. Repayments were postponed if the wife was pregnant within six months and completely canceled with the birth of a fourth child. The age restriction is ironic given that the tax on celibacy applied to men aged 25 to 65 ; hence the loans could not work as an incentive to encourage this group of men to marry.

Financial assistance was made available to large families; however, there were contradictions in these programs. For example, a large family had to comprise either "ten or more dependent children or twelve or more children born live of whom at least six were still dependent" (Caldwell 1986:119). Even then, the assistance to qualifying large families was often minimal. 
The effects of the Duce's demographic policies took their harshest toll on the lower-class peasants of the south. The proverb piu famiglia, più fame (more family, more hunger) was well-known in the south, and the tendency was emerging for the largest families to be poorest (Schneider and Schneider 1984:259).

The policies enacted as part of the demographics campaign to encourage large families often had a disproportionate impact on the subaltern class (c.f. Gramsci 1971). The impact of bans on birth control hit the poor especially hard. The new fascist penal code placed contraception (once advocated by Mussolini) and informational material in its favor under heavy penalty. In the code of 1931, abortion was positioned among the "crimes against the wholeness and health of the race" (Caldwell 1986:121; Hellman 1987:32). Women with greater means had access to safer underground abortions than those with lesser means.

Limits on women's work had more negative consequences for lowerclass women than for the bourgeoisie. Women's emancipation was viewed as among the possible motives that caused women to manage their fertility (de Grazia 1992:49). Mussolini expressed the view in 1930 that, "Work, where it is not a direct impediment, distracts from conception. It forms an independence and consequent physical and moral habits contrary to child bearing" (in de Grand 1976:958). The fascist moral order was strengthened in 1930 with the Catholic Church's encyclical, issued by Pius XI, which described women's work outside the home as a corruption of the role of wife and mother and a "perversion" of the family (Birnbaum 1986:37). From 1926 to 1933, whenever men's salaries were reduced, the wages of women were cut to half of those of men. The new civil code between 1939 and 1942 defined and regulated the family as a social and political institution (Saraceno 1990:436), and regulations forbidding women from leaving the "conjugal home "without just cause' were reinforced" (Saraceno $1990: 440$ ). The decree law of 1938 called for a reduction of women to 10 percent of public and private office staffs and excluded women entirely from offices with less than ten employees, of which a large number of Italian businesses were comprised. This law met with opposition; however, it was probably Italy's entrance into World War II that explains why the law remained inoperative in 1940 (Noether 1982:73). In addition to laws, discourses continued to degrade the role of working women. In 1940, the First National Congress of Women Workers in Commerce issued the statement: "It is a basic fact that work constitutes not a life goal for a woman, but a stage in her life, one to be finished up as soon as possible with her return to the home environment" (de Grazia 1992:166). Such divisions of life stages were not within the grasp of peasant and working-class women. 


\section{Strategies of Legitimation}

Bernard Cohn and Nicholas Dirks have pointed out that documentation projects are one of the officializing procedures through which nation-states render themselves legitimate. Documentation projects involve "constant reiteration" of state power through what become "accepted as natural state functions, of certifying, counting, reporting, registering, classifying, and identifying" (1988:224). Demographic policies were one area in which documentation efforts were highly visible and intrusive.

The goal of nation-building, of reproducing and raising an "imagined community" of Italians, also made use of the media. Propaganda in various forms helped the nation-state to command "emotional legitimacy" (Anderson 1991:4). The fascist project is interesting to consider in light of Anderson's analysis of the emergence of modern nation-states and the "half-fortuitous, but explosive, interaction between a system of production and productive relations (capitalism)" and "a technology of communications (print)" (1991:42). The variegated media that carried propaganda, which are a subset of the category of print-capitalism that Anderson describes, provided "the key to the generation of wholly new ideas of simultaneity" (Anderson 1991:37).

The regime's broad efforts at legitimation can be seen as an attempt to impose on its subjects a particular vision of their role in furthering the state project. Prime examples of the fascists' state-building strategies can be located in three places: organizations, such as the Opera Nazionale Maternita ed Infanzia (ONMI); documentation projects, namely those related to tracking demographic and fertility statistics; and propaganda, especially posters and films geared at creating national images of and roles for women.

Organizations. The ONMI represented a way to legitimize the demographic campaign and in the process sought to modernize maternity. An extension of the state into the family domain resulted in a general suppression of women's rights. The mother's welfare was subordinated to that of her infant (de Grazia 1992:60). This was consistent with the fascist racial policy, in which a sexual hierarchy within the Italian "race" itself paralleled "the hierarchy of races" (de Grand 1976:957), with woman at the bottom of the heap, her authority in the family diminished. Social workers and medical professionals undermined the control that female networks of kin and community had traditionally exercised over childbirth and infant nurturance. The new childrearing standards, along with stigmatization of traditional practices, received support from the global capitalist system. Italian companies and British, Swiss, and American pharmaceutical 
and food industries pushed products such as Nestlé's infant formula, cleansers, medicines, and baby foods using modem marketing strategies (de Grazia 1992:65).

This commodification and medicalization of childbirth was furthered by the work of the ONMI. The practice of midwifery, according to de Grazia (1992:65), "was becoming more professionalized, more subordinated to male medical hierarchies, and more distant from the female patients and kinship networks with which the midwives had formerly collaborated." Even the bourgeoisie could not escape this trend. De Grazia (1992:68) offers a priceless anecdote about Rachele Guidi, Mussolini's wife, who was nearly driven crazy with the doctor's "new methods" (nuovissimi metodi), which involved intrusive monitoring. Immediately following the September 26,1927, birth of Guidi's fourth child, an argument broke out between the doctor and midwife over who should be credited in the press release, to which the mother interrupted: "Really, it was I who brought my son into the world" (Mi sembra, di essere stata io, veramente, a mettere al mondo mio figlio). Similar constrictions of female authority within the household were occurring in more humble households (de Grazia 1992).

State repression of birth control went hand-in-hand with state efforts to modernize matemity practices. Women who lost by the former might gain from the latter, although in both instances, arguably, their capacity to control their own bodies had decreased (de Grazia 1992:59).

Documentation projects. Families under fascism were subjected to numerous documentation projects. The ONMI's surveillance mode manifested itself in the realm of unwed mothers and their "illegitimate" offspring. To prevent single women from aborting, the agency provided free checkups and modest financial support. This social-welfare project allowed the state a point of control into the private lives of women and a way to keep a sharp gaze on their conceptions. The latter half of the 1930 s witnessed an intense debate over a never-implemented proposal to require that all pregnancies be declared and then "kept under surveillance" (Passerini 1987:176).

Most intrusive was the plethora of commissions and agencies set up to monitor the population, beginning in 1926. Through the Central Institute of Statistics, Italians were subjected to all sorts of surveys as population statistics rapidly developed as a field of study (de Grazia 1992:48). There were dire prophesies about racial exhaustion. The statisticians also searched for an ideal physiology for maternal and paternal types. This project proved inconclusive: "The best that could be determined 
regarding women was that 'proliferous females' were shorter rather than taller, broader around the hips than narrower, and more slovenly than elegant" (de Grazia 1992:49).

Propaganda. The film Madri D'Italia (Mothers of Italy), produced by the ONMI, offers insight into the fascist ideal of motherhood, an ideal riddled with contradictions. The central contradiction was the way in which potential mothers were depicted as compared to actual mothers: Potential mothers were shown as fashionable, hat-donning belles pictured among blooming trees-young, innocent, and beautiful; the actual mothers were portrayed as rather slovenly, asexual peasant women (Caldwell 1991:45). Femininity was reduced to constant reproduction (Caldwell 1991:51). A rural context was idealized as the locus of the pure Italian family; apparently, neither the fascist state nor its propaganda grappled with the ways in which these naturalized images of women contradicted Mussolini's goals of modernization. Peasant women were known to be more prolific than urban women, and it was this notion that was being played upon.

Set within the context of the demographic campaign, the film had two direct purposes: It sought to encourage women to reproduce and then to teach them about the duties and responsibilities that followed childbirth in order to raise a strong and healthy child. A central message in the film was to subordinate personal desires to national aims. In one shot, a sturdy woman smiled down as though at a child; a massive image of Mussolini, "a heroic figure, "loomed in the background. Mussolini became the source of a mystical union of births, nation-building, and war (Caldwell 1991:54).

The ideal of desexualized mothers in service to the state was similarly communicated through ONMI posters designed to celebrate Mother and Child's Day. The artist rendered the fascist women as faceless, stylized, and devoid of individuality; the infant is sturdy and often prominently featured being lifted up or held out. It is interesting to note that the poster's designer, Marcello Dudovich, was Italy's most renowned commercial artist, known for his art nouveau designs of Italian emporia illustrating glamorous bourgeois women out alone-the antithesis of the fascist ideal of prolific motherhood, the comely peasant girl. De Grazia (1992:73) notes that fascist propaganda manufactured two female images: donna crisi ("cosmopolitan, urbane, skinny, hysterical, decadent, and sterile") and donna madre ("national, rural, floridly robust, tranquil, and prolific").

Fascist propaganda established an opposition between unhealthy and healthy women. Healthy women were depicted as slovenly and inelegant, since elegance was viewed as a detriment to fecundity (Caldwell 1991:49). "For fascism," writes Caldwell (1991:51), " 'real' femininity lay in the 
capacity to reproduce, and its propaganda sought to exploit those aspects of traditional Italian life that underlined these capacities." At stake in these propaganda campaigns was the politics of proliferation. The reinscription of gender roles served the purpose of legitimizing the nation-state as the family writ large.

\section{Public Ritual as Consensus Builder}

The public was not so quick to accept the dictator's call to arms-or rather, to babies. Given that one form of resistance has been described with the term "reverse gear,", if we continue the metaphor by imagining the fascist state project as a car, one might suggest that the car was up on blocks much of the time. In this sense, its forward gears did not function in the way the dictatorial regime would have liked; perhaps the Italian fascists never really got out of first gear.

Italians were divided on the issue of desirable family size, and in part these divisions fell along urban/rural and bourgeois/working-class lines. The misfit between reality and fascist propaganda on demographic policies led working people to conclusions that were not what fascists had hoped for: "That the rich had few children and the poor many caused resentment not only against the wealthy but also against a regime that tolerated such inequalities of burdens and means" (de Grazia 1992:73).

Numerous scholars have written about the powerful role of ritual as a means of legitimizing state power and of making this power visible. Eric Hobsbawm has noted that invented traditions of modem nations "generally claim to be the opposite of novel, namely rooted in the remotest antiquity, and the opposite of constructed, namely human communities so 'natural' as to require no definition other than self-assertion" (Hobsbawm 1992 [1983]:14). Invented traditions can be seen as a process of creation, one which is integral to Italian history. As Roseberry (1982) has so persuasively argued, culture is not simply a product but is also production.

Richard Fox's definition of national culture is especially useful in this context of nation-building and cultural production. He views national culture as malleable, the outcome of an ongoing process of cultural production. "A national culture is constantly being molded as individuals and groups confront their social worlds and try to (re)form them. Out of such confrontations emerge nationalist ideologies from which, in turn, a national culture gets produced" (1990:2). He argues that nationalist ideologies anticipate the larger project of national culture. But, as we have seen, internal contradictions and challenges to the dominant ideology from below, as Fox writes, "make a national culture rubbery" (1990:5). 
Several Italian fascist public rituals can be viewed as attempts to convert the "rubber" into a "hard plastic." I will discuss three of these attempts at legitimation, which were linked to the demographics campaign: Mother and Child's Day, the Ring Ceremony, and the annual convocation of prolific couples.

The first Mother and Child's Daywas held in 1933, and the chosen date of December 24 clearly exploited the Catholic cult of the Virgin Mary. The ceremony was intended to honor mothers as bearers and nurturers of children. However, the objects of celebration were not just any mothers but extremely prolific ones. The Duce presided over the national rally, held in Rome. The most prolific mother from each of Italy's 90 provinces “was passed in review like prize breeding stock. The role call trumpeted not her name but the number of her live births: fourteen, sixteen, eighteen" (de Grazia 1992:71). The coverage of the event was nationalistic as the title on this newsreel shows: "Ninety-three of Italy's most prolific mothers who paid their respects at the tomb of the Unknown Soldier on Mother and Child Day" (Caldwell 1991:50). The link to national culture is clear. Cenotaphs rank among the most compelling emblems of nationalism (Anderson 1991). Such images are central to the imagining of the nationstate, for they help to secure its status as a deeply rooted, historically secure entity whose presence looms "out of an immemorial past" (Anderson 1991:15).

The Ring Ceremony, also known as the Day of Wedding Rings, was a powerful one-time ritual. Designed to help the Ethiopian war cause, women on December 18, 1935, were asked to hand over their gold wedding rings in exchange for iron ones. The symbolism of the ritual did not go unnoticed: The act of handing over a ring appeared to seal a new union between Italian women, families, and the fascist state. "It was," Caldwell writes (1991:54), drawing on Macciocchi's (1979) observation, "as if Mussolini had become the Husband in a mystic marriage dedicated to war and births." But the message was confused: Was a woman's first obligation to "the Duce, fascism and the nation, or to her spouse, children and kin as decreed by custom, sacred church vows, and pronatalist slogans?" (de Grazia 1992:77) Other problems were the uneven burden placed on women (depending on class) and the disproportionate sacrifices of povertystricken women compared to the scant profits accrued in the state treasury that resulted from their donation (de Grazia 1992:77-78)

The annual convocation of prolific couples was an effort to erase the tension between family obligations (i.e., how many children two adults could realistically support) and national duties (i.e., the production of many 
offspring). This ritual, held in the Palazzo Venezia, began in 1933. Strict eligibility rules were redefined each year. The basic criteria were political loyalty and a minimum of 12 living children; however, offspring who had died in war or for the national cause might be counted. Illegitimate offspring were not included under any circumstances. The award by 1935 was substantial: 4,000 lire plus an insurance policy of 1,000 lire. The monetary amount exceeded a skilled worker's annual income (de Grazia 1992:92).

Despite efforts to valorize prolificity, the hegemony of the state-its rule through political, social, and cultural forces (c.f. Williams 1977)remained vulnerable as evidenced by acts of everyday resistance. The results of the fascist's own documentation projects verify the failure of efforts to increase population (see Table 1).

Birth rates declined severely in the ten-year period between 1922 and 1932 from 30.7 to 23.6 births per 1,000 people. It is also worth noting that the Central Institute for Statistics was not an independent agency but rather fell under the direct control of the prime minister. Statistics were frequently manipulated if they painted too bleak a picture (Ebenstein 1934:172). So, even if the birth-rate trend had been altered, the figures "show up clearly the fiasco of Mussolini's propaganda, which ended in having the opposite effect from what he intended" (Ebenstein 1934:172).

Livi-Bacci, an expert on Italian fertility, offers a more cautious assessment: "Complex pronatalist policies such as the Italian one cannot offset long-term tendencies" (1977:278). Livi-Bacci described the longrange effects of the fascist demographic policy as "modest, if any existed at all." The trend of declining fertility can be traced to the $1880 \mathrm{~s}$, when 36.3 births per 1000 were average, as compared to the 1945 rate of 19.9 births per 1000. Certainly modernization, industrialization, and urbanization

Table 1. Birth Rates per 1000 inhabitants, by region, 1921-45.

\begin{tabular}{llllll}
\hline Year & Italy & North & Central & South & Islands \\
\hline $1921-25$ & 29.9 & 26.6 & 28.2 & 36.3 & 31.0 \\
$1926-30$ & 27.1 & 23.5 & 24.7 & 33.8 & 29.9 \\
$1931-35$ & 24.0 & 20.3 & 21.5 & 30.8 & 27.2 \\
$1936-40$ & 23.4 & 19.8 & 21.2 & 29.7 & 27.2 \\
$1941-45$ & 19.9 & 16.6 & 17.5 & 25.3 & 24.2 \\
\hline
\end{tabular}


played a role in declining birth rates. However, to look only at these forces is to deny individual agency, conscious decision-making, and resistance of the people living under fascism (Passerini 1987).

\section{Conclusion}

Numerous Italian laws, decrees, propaganda, honors, and public rituals were directed at creating a body politic divided along lines based on essential ideas of manhood and womanhood-loyal masses who would feed the nationalistic war organ of the state with the products of female subjects' wombs. The Duce's government was "the first in Italy to make family values central to the art of statecraft" (de Grazia 1992:80), and the project has had lasting effects (Bono and Kemp 1991). The regime employed numerous tactics to impress on its citizenry the "civic obligations, collective virtues, and personal values" necessary to nation-states in a competitive world system (de Grazia 1992:6). Gendered subjects were polarized, and women were narrowly defined. “Mussolini's regime stood for returning women to home and hearth, restoring patriarchal authority, and confining female destiny to bearing babies," as de Grazia puts it (1992:1).

The fascist state's policies, particularly the politics of proliferation, affected people in serious ways, yet people did not consent to the dominant ideas in a lock-step fashion. This leads one to inquire whether Italian fascism was "totalitarian" in the sense that the state held primacy over civil society and the individual. Forgacs' (1986:2) suggestion that Italian fascism was "at best an imperfect or 'flawed' totalitarianism" becomes particularly convincing when resistance, located largely in bodies and expressed in memories of the everyday, is figured into the analysis.

Given that fascism portrayed the ideal woman as a desexualized peasant mother, one might conclude that the fascist state was rejecting the modernizing industrialist forces of the time. This was hardly the case. Declining birthrates were a feature of modernity, and it was simply one feature that Mussolini wanted to reverse. The fascist state appropriated images of traditional motherhood to achieve its demographic ends. Women were simultaneously cast at the center and periphery of the fascist state: as political subjects - typically an urban attribute-and as biological breeders-placed in the rural hinterlands. Nor should resistance to fascist demands to make babies be interpreted along heavily demarcated lines of people rejecting or accepting modernity. Further research would be needed to sort out how choices to control fertility related to attitudes about a more industrialized Italy. Distinctions drawn between modernity and premodernity - e.g., equating images of peasant women with "tradition" - quickly 
break down in the context of gender and the Italian fascist state-building project.

Using gender as a tool for historical analysis has helped to demystify the dictator's attempt to reify and cast legitimacy on the fascist state: that of constructing the state as the "family writ large" in order to penetrate his discourse into the everyday lives of his subjects. But, as we have seen, the fascist state's invasive policies backfired and created spaces for resistance, for there are limits to the intimate corners into which the state's gaze can penetrate. The making of history, even under regimes that seek to totalize, is a dialectic process, one in which paradox plays an important role in encouraging the back-and-forth maneuvering of historical forces. Our understanding of histories is enriched by approaches that "debunk essentializing categories, " as Silverblatt (1988:429) has noted. Oral histories become a powerful tool for amplifying specific gendered voices, voices that conventional histories muffle.

\section{Notes}

'I would like to acknowledge Dr. Daniel Nugent for his thoughtful suggestions to an earlier version of this paper. This paper also benefitted from the friendly criticisms of Daniel Goldstein and Valerie Sacks. I accept full responsibility for any deficiencies, with the qualifier that any work is always "in progress."

${ }^{2}$ The problematic nature of racial categories is especially apparent in the Italian case. Further research is needed into what Mussolini viewed as "racial" purity. There has long been tension between Northern and Southern Italians, a tension that is readily apparent through contemporary derogatory comments. While in Italy in 1984, I recall several resentful remarks made by my Florentine friend toward Southerners (e.g., their loud mode of personal communication, their practice of migrating into the city and "taking jobs and women," etc.). However, the literature about fascism seems to gloss over these tensions. Schneider and Clough cite Slavs, Croats, and Germans as the ethnic minorities whom Mussolini targeted in his severe policy of Italianization (1929:47).

${ }^{3} \mathrm{~A}$ review of the literature on Italian fascism reveals a similar omission. The role that women played in Italian fascist state formation has often been ignored (c.f. Ebenstein 1934, Schneider 1928, Schneider and Clough 1929) or dealt with only minimally (Thompson 1991). This oversight is especially noticeable in Schneider and Clough's chapter on "Patriotic Organizations," in which the authors' list of five types of organizations emphasizes the masculine aspects of the state-legitimizing project. Under youth organizations, they devote four pages to the types of instruction for boysnamely physical, fascist, moral, patriotic, and military-and less than a half page to instruction for girls. What they note about the purpose of the girls' youth groups, however, is interesting in light of the view of fascism as the family writ large: "To serve the Nation as her other and greater mother, the mother of all good Italians; to love the Duce who has made the Nation stronger and greater."

The National Foundation for the Protection and Aid of Mothers and Children was also given scant attention. The authors only briefly mention the organization's role 
in the demographic movement to augment the birth-rate and to care for infants and children. The chapter on "Fascism and Catholicism" writes women, and the cult of the Virgin Mary, out of history.

${ }^{4}$ Men taxed for celibacy were required to pay a standard amount each year plus 25 percent of total income

\section{ReferRancis}

Abrams, Philip. 1988. Notes on the Difficulty of Studying the State. Joumal of Historical Sociology l(1):58-89.

Alonso, Ana Maria. 1988a. The Effects of Truth: Re-Presentations of the Past and the Imagining of Community. Journal of Historical Sociology 1(1):33-57.

Alonso, Ana Maria. 1988b. "Progress" as Disorder and Dishonor: Discourses of Serrano Resistance. Critique of Antbropology 8(1):13-33.

Anderson, Benedict. 1991. Imagined Communities: Reflections on the Origins and Spread of Nationalism. London: Verso.

Barbagli, Marzio, and David Kertzer. 1990. An Introduction to the History of Italian Family Life. Jourmal of Family History 15(4):369-384.

Birnbaum, Lucia Chiavola. 1986. Liberazione della donna: feminism in Italy. Middletown, Conn.: Wesleyan University Press.

Bono, Paola, and Sandra Kemp. 1991. Italian Feminist Thought. Oxford: Basil Blackwell. Caldwell, Lesley. 1986. Reproducers of the Nation: Women and the Family in Fascist Policy. In Retbinking Italian Fascism . David Forgacs, ed. Pp. 110-141. London: Lawrence \& Wishart.

Caldwell, Lesley. 1991. Madri d'Italia: Film and Fascist Concern with Motherhood. In Women and Italy: Essays on Gender, Culture, and History. Zygmunt G. Baranski and Shirley W. Vinall, eds. Pp. 43-63. London: MacMillan Academic and Professional Ltd.

Cohn, Bernard S., and Nicholas B. Dirks. 1988. Beyond the Fringe: The Nation State, Colonialism, and the Technologies of Power. Joumal of Historical Sociology 1(2):224-229.

Corrigan, Philip, and Derek Sayer. 1991. The Great Areb: English State Formation as Cultural Revolution. Oxford: Basil Blackwell.

de Grand, A. 1976. Women Under Italian Fascism. Historical Joumal 19(4):947-968.

de Grazia, Victoria. 1992. How Fascism Ruled women: Italy 1922-1945. Berkeley: University of Califomia Press.

Ebenstein, William. 1934. Fascism at Work. New York: AMS Press.

Forgacs, David. 1986. Introduction: Why Rethink Italian Fascism? In Retbinking Italian Fascism . David Forgacs, ed. Pp. 1-10. London: Lawrence \& Wishart.

Fox, Richard. 1990. Introduction. In Nationalist Ideologies. Richard Fox, ed. Pp. 1-14. Washington, D.C.: American Anthropological Association.

Fox-Genovese, Elizabeth. 1982. Placing Women's History in History. New Left Review 133:5-29.

Gramsci, Antonio. 1971. Selections from the Prison Notebooks. New York: International Publishers.

Guha, Ranajit, and Gayatri Chakravorty Spivak, eds. 1988. Selected Subaltern Studies. Oxford: Oxford University Press.

Hellman, Judith Adler. 1987. Journeys Among Women: Feminism in Five Italian Cities. New York: Oxford University Press. 
Hobsbawm, Eric. 1992 (1983). Introduction: Inventing Traditions. In The Invention of Tradition. Eric Hobsbawm and Terence Ranger, eds. Pp. 1-14. Cambridge: Cambridge University Press.

Lefebvre, Henri. 1988. Toward a Leftist Cultural Politics: Remarks Occasioned by the Centenary of Marx's Death. In Marxism and the Interpretation of Culture. L Grossberg \& C. Nelson, eds. Pp. 75-88. Macmillan Education.

Livi-Bacci, Massimo. 1977. A History of Italian Fertility. Princeton: Princeton University Press.

Macciocchi, M. 1979. Female Sexuality in Fascist Ideology. Feminist Review I:67-82.

Noether, Emiliana P. 1982. Italian Women and Fascism: A Reevaluation. Italian Quarterly 23:69-80.

Passerini, Luisa. 1979. Work Ideology and Consensus under Italian Fascism. History Workshop 8:82-108.

Passerini, Luisa. 1982. Work Ideology and Working Class Attitudes to Fascism. In Our Common History: The Transformation of Europe. Paul Thompson with Natasha Burchardt, eds. London: Pluto Press.

Passerini, Luisa. 1986. Oral Memory of Fascism. In Rethinking Italian Fascism. D. Forgacs, ed. Pp. 185-195. London: Lawrence \& Wishart.

Passerini, Luisa. 1987. Fascism in Popular Memory: The Cultural Experience of the Turin Working Class. Cambridge: Cambridge University Press.

Popular Memory Group (PMG). 1982. Popular Memory: Theory, Politics, Method. In Making Histories: Studies in History Writing and Politics. Richard Johnson, Gregory McLennan, Bill Schwarz, and David Sutton, eds. Pp. 205-252. Minneapolis: University of Minnesota Press.

Roseberry, William. 1982. Balinese Cockfights and the Seduction of Anthropology. Social Research 49(4):1013-1028.

Roseberry, William. 1992. Hegemony and the Language of Contention in Gramsci and Williams. Paper presented at the 1992 meeting of the Canadian Anthropological Society. Manuscript.

Saraceno, Chiara. 1990. Women, Family and the Law, 1750-1942. Joumal of Family History 15(4): 427-442.

Sayer, Derek. 1991. Everyday Forms of State Formation: Some Dissident Remarks on "Hegemony." Manuscript.

Schneider, Herbert W. 1928. Making the Fascist State. New York: Oxford University Press. 
